\title{
A Látrányi Puszta Természetvédelmi Terület növényzetéröl
}

\author{
LÁJER KONRÁD
}

Pécsi Tudományegyetem, Biológiai Intézet, Növénytan Tanszék H-7624 Pécs, Ifjúság útja 6., Hungary

LÁJER K: On the vegetation of the Látrányi Puszta Nature Conservation Area

Abstract: "Látrányi puszta" is a protected area in Somogy county, Hungary. The plant communities of this area were investigated by the methods of classical phytosociology. The following associations were found: Phragmitetum communis, Typhetum angustifoliae, Typhetum latifoliae, Cladietum marisci, Bolboschoenetum maritimi, Caricetum elatae, Caricetum acutiformis, Caricetum ripariae, Carici gracilis-Phalaridetum, Juncetum subnodulosi, Junco obtusiflori-Schoenetum, Eleocharidi uniglumi-Eriophoretum angusifolii, Cirsietum rivularis, Succiso-Molinietum hungaricae, Agrostio-Deschampsietum caespitosae, AstragaloFestucetum rupicolae, Cirsietum lanceolati-arvensis, Rudbeckio-Solidaginetum, Bromo sterilis-Robinietum and some others (Alnion fraction, not specified ruderal communities, wood plantations). The occurrences of diagnostic, typical, protected, invasive or other remarkable species are detailed.

Key words: fen, grasslan, phytosociology, association, habitat, conservation

\section{Bevezetés}

A kutatás tárgya az 1992-ben KTM rendelettel országos jelentőségü védett természeti területté nyilvánított, 223,5 ha-ra kiterjedö Látrányi Puszta Természetvédelmi Terület növényzete. Tengerszint feletti magassága 116,8-143,1 m (átlagosan $130 \mathrm{~m}$ ). Éghajlata mérsékelten meleg-mérsékelten nedves. A vegetációs időszak középhőmérséklete 16,8$17,2^{\circ} \mathrm{C}$, évi csapadékösszeg $650 \mathrm{~mm}$, amiből $400-420 \mathrm{~mm}$ a vegetációs időszakban hullik. Felszínét negyedkori üledékek fedik: a Balaton egykori öblözetében felhalmozódott tavi homokot az északias irányból fújó szél áthalmozta és a terület magasabb, nyugati részén buckákat épített (relativ magasságuk ma kb. $10 \mathrm{~m}$ ). Az alacsonyabb, keleti részen a Tetves-patak üledékei találhatók a felszínen. A talajvíz átlagos mélysége a völgyekben 2-4 m, a lápréteken azonban a felszín közelében található. Kalcium-magnéziumhidrokarbonátos jellegü, 25-35 német keménységi fokú. A talajvíz mozgása északkeleti irányú. A vizsgált terület $70 \%$-át karbonátos homokos váztalaj fedi, $10 \%$-án humuszos homoktalajok fejlődtek. A tartósabban nedves felszineket rétláp talajok borítják. Itt átszivárgásos lápok is találhatók érdekes üde lápréti növényzettel.

A terület történetéröl rendelkezésre álló szórványos adatok szerint a 14. században királyi birtok volt, majd a 20. századig különböző fớri családok birtoka. Az első katonai felmérés (1782-85) térképszelvénye a maihoz hasonló pusztának ábrázolja a területet, amelynek csak délkeleti részein vannak fás ligetek. A területet azóta (és jelenleg is) részben legelöként hasznosítják. A láprétek egy részét a természetvédelmi hatóság (kezelö) bekeríttette.

A lápi és nedves réti társulások nagy részét korábban (LẢJER 1998a) regionális keretben tárgyaltam, néhány érdekesebb florisztikai adatot külön közöltem (LÁJER 1998c).

Ebben a közleményben 1996-2002 években folytatott vizsgálataim eredményeit ismertetem. A vizsgált területet is magában foglaló, 5 földrajzi hosszúsági perc x 3 széles- 
ségi perc méretü (kb. 5.5 x $6 \mathrm{~km}$-es) kvadrát részletesebb florisztikai felmérését a hazai hálórendszerü flóratérképezés keretében 2003 (-2004)-ben fogom befejezni, ennek során sor kerül egyes növénytársulások további vizsgálatára is.

\section{Módszerek}

A terepi munkálatokat 1996-2002 években, májustól novemberig végeztem. A cönológiai felvételeket Braun-Blanquet módszerrel, tipikus, viszonylag homogén vegetációjú élőhelyről készítettem. Az egyes állományokat florisztikai összetételük és fiziognómiájuk, valamint egyéb ökológiai szempontok (terepdőlés, vízellátottság, stb.) alapján határoltam körül. A mintaterület nagyságát tapasztalati ajánlások figyelembevételével (DIERSCHKE 1994: 10-25 $\mathrm{m}^{2}$ ), továbbá arra tekintettel határoztam meg, hogy a mintaterület a vegetáció összetétele és szerkezete szempontjából homogén legyen. $25 \mathrm{~m}^{2}$ területü négyzet, illetve $10 \mathrm{~m}^{2}$-es téglalap megfelelőnek bizonyult. A gyakoriság-borítás (A-D) értékek becslésénél a finomított Braun-Blanquet skálát alkalmaztam. A beillesztett és módosított kategóriák:

$1=$ borítás $<5 \%$, egyedszám $>50$

2 = borítás $5-15 \%$, egyedszám tetszőleges

$3=$ borítás $15-25 \%$, egyedszám tetszöleges.

Az asszociációkat és magasabb syntaxonómiai egységeket diagnosztikus értékü fajaik alapján, a fiziognómia figyelembevételével értékeltem.

A felvételi táblázatokban a fajokat elsösorban a BoRHIDI (1995) szerinti cönológiai csoportokba való besorolásuk szerint adtam meg, bár néhány esetben, a helyi sajátosságok figyelembevételével, kissé eltérő besorolást alkalmaztam. A syntaxonómiai kategóriák sorrendjét általában az adott társuláshoz való kapcsolat, illetve az alacsonyabb-magasabb rang határozta meg.

A fajok neveit illetően SimON (2000) munkáját követtem. A társulás nevezéktan korábbi (idézett) munkáimnak, illetve a társulások vörös könyvének (amelynek társszerzője vagyok, BORHIDI és SÁNTA 1999) megfelelő, további irodalmi hivatkozások ott találhatók.

\section{Eredmények}

A vizsgált területen az alábbi növénytársulások voltak kimutathatók:

1. Nádas (Phragmitetum communis Soó 1927 em. Schmale 1939)A Phragmition társuláscsoport központi helyzetü asszociációja, mely mezotróf-gyengén eutróf vizekben jellemző és az alkalikus vizeket is elég jól bírja. Területünkön gyakoribbak az elgyomosodott, degradált állományok, természetesebb foltjaikat csak a legmélyebb fekvésü részeken találunk. A domináns nád (Phragmites communis) mellett gyakori kísérőfaja a közönséges lizinka (Lysimachia vulgaris) és a vízi menta (Mentha aquatica). A nád állományok túlnyomó része valójában üde lápréteken (mint leromlási stádium) található.

A Tetves-patak mentén a 2. keskenylevelü (Typhetum angustifoliae) és 3. széleslevelü gyékényes (Typhetum latifoliae) kicsiny, fajszegény állományfoltjai is megtalálhatóak.

4. Télisásos (Cladietum marisci Zobrist 1935)

Kovács (1955) Fonyód és Balatonboglár között készült felvételei alapján közölt szin- 


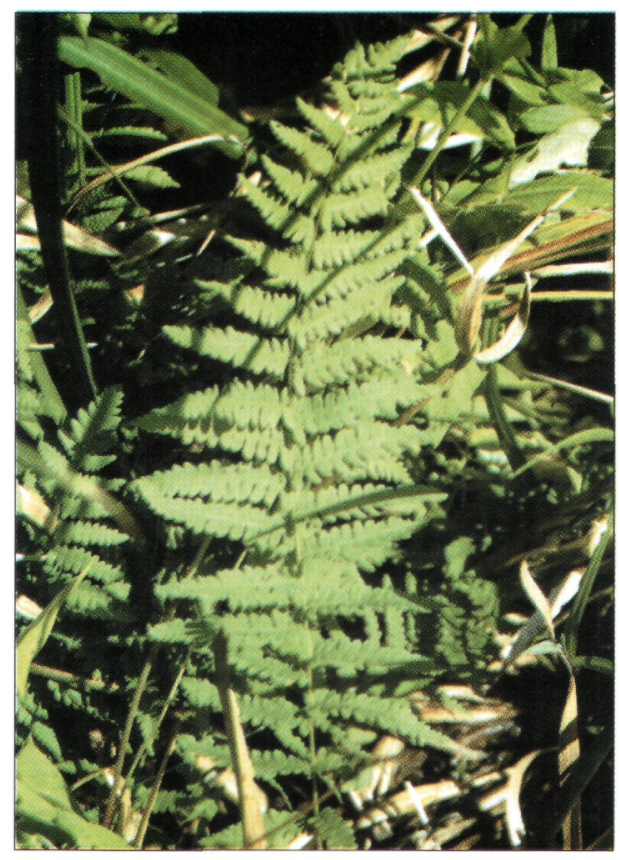

1. ábra:Tőzegpáfrány (Dryopteris carthusiana)

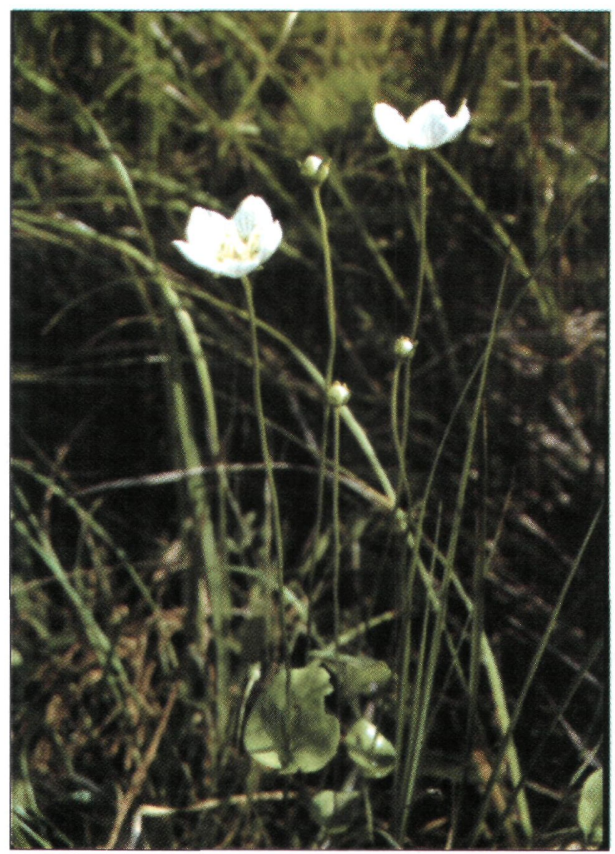

2. ábra: Féhér májvirág (Parnassia palustris) 


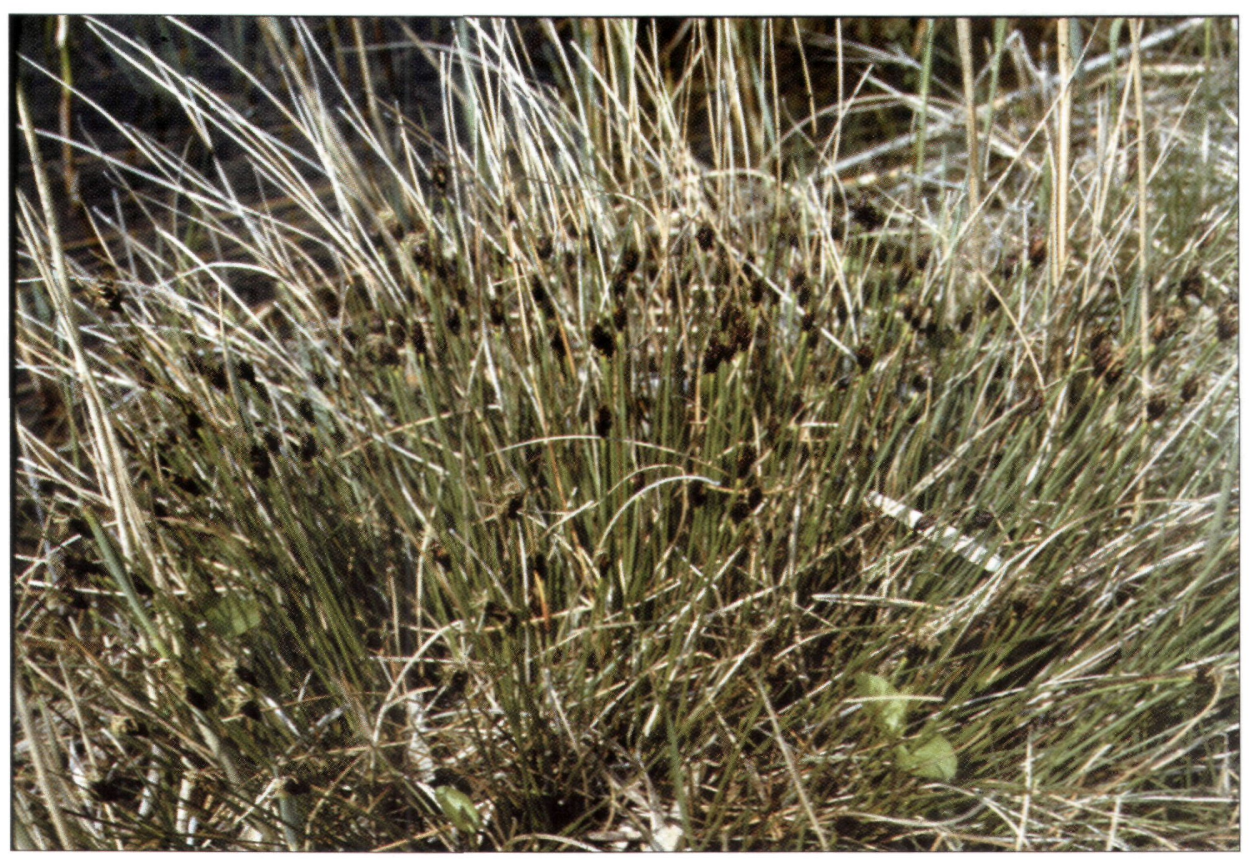

3. ábra: Kormos csáté (Schoenus nigricans)

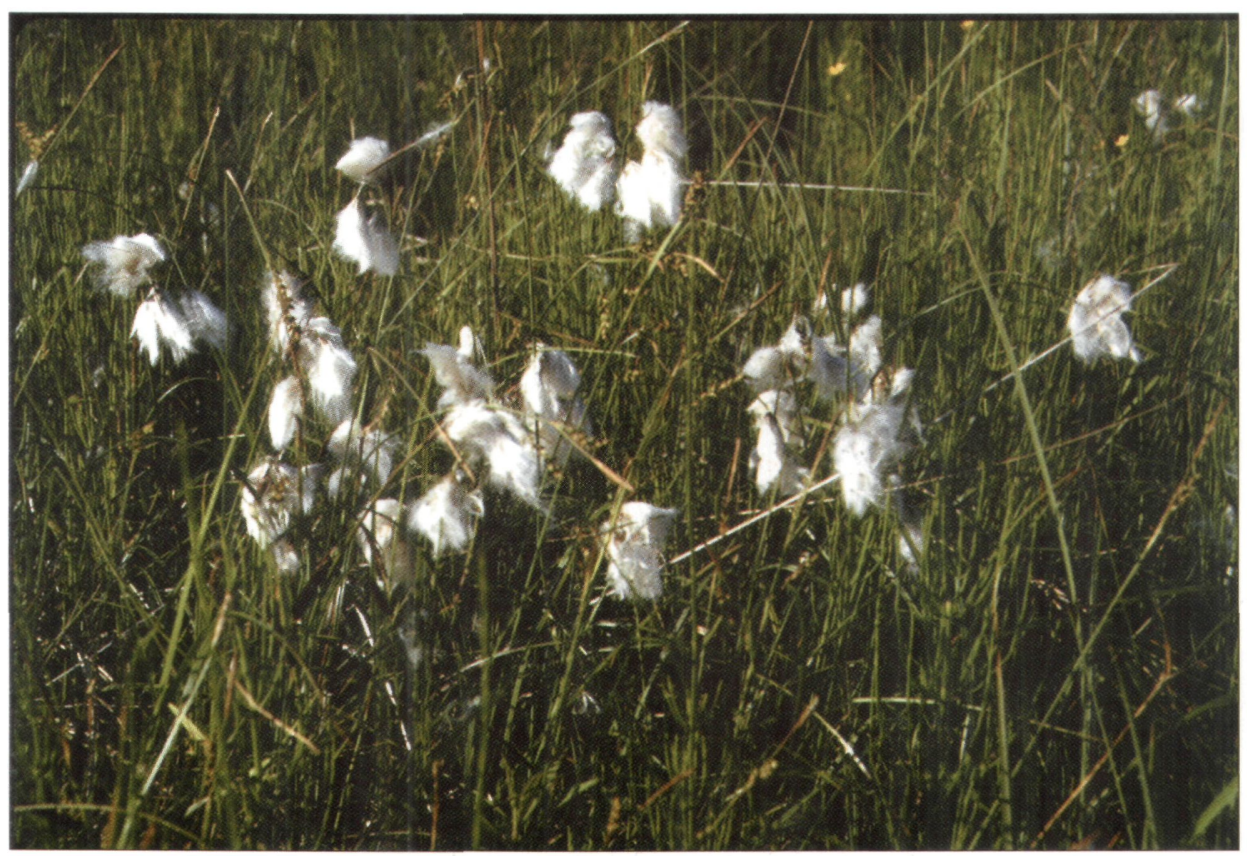

4. ábra: Széleslevelú gyapjúsás (Eriophorum latifolium) 
tetikus táblázatokat, továbbá elemezte ezt a társulást. Magam a vizsgálati területet kiterjesztettem (LÁJER 1998a) nyugat felé Balatonkeresztúrig, keleti irányban pedig Látrányig, ahol kicsiny állományfoltja található. Hasonló állományait vizsgáltam a Marcal-medencében (LÁJER 1997).

A Cladietum jellegzetes, sürü, nehezen járható állományaiban a domináns Cladium mariscus mellett alig fordul elő egyéb edényes növényfaj. Szálanként viszonylag gyakran találkozhatunk a közönséges lizinkával (Lysimachia vulgaris) és a réti füzénnyel (Lythrum salicaria).

Társulás felvétel (év: 1997, területnagyság: $25 \mathrm{~m}^{2}$ ): Cladium mariscus 5, Cirsium rivulare 1, Phragmites communis 1, Solidago gigantea 1, Lycopus europaeus +, Lysimachia vulgaris + , Valeriana dioica + .

\section{Sziki kákás (Bolboschoenetum maritimi Eggler 1933)}

Ingadozó vízállású, szikesedő mélyedésben találjuk kicsiny, magassásosra emlékeztető, szőnyegszerü állományát. A szikes mocsár- és rétfoltok a Balatontól délre egyébként több helyen megjelennek (pl. Balatonfenyves, Fonyód, Ordacsehi), olyan kísérő fajokkal, mint a sziki őszirózsa (Aster tripolium), sziki útifü (Plantago maritima), tengerparti szittyó (Juncus maritimus). Társulás felvétel (év: 2002, területnagyság: $25 \mathrm{~m}^{2}$ ): Bolboschoenus maritimus 5, Galium palustre 1, Mentha aquatica 1, Schoenoplectus tabernaemontani 1, Alisma plantago-aquatica 1, Lythrum salicaria 1, Ranunculus repens 1 , Lycopus europaeus + .

\section{Zsombéksásos (Caricetum elatae Koch 1926)}

Az elsösorban mezotróf vizek feltöltődésében szerepet játszó, tipikus zsombéklápot alkotó társulás. A vizsgált területen csak kis kiterjedésú állománya $\left(30-40 \mathrm{~m}^{2}\right)$ fordul elö. Társulásfelvétel (év: 2002, területnagyság: $25 \mathrm{~m}^{2}$ ): Carex elata 4, Mentha aquatica 1, Schoenoplectus tabernaemontani 1, Alisma plantago-aquatica 1, Lythrum salicaria 1, Equisetum palustre +, Galium palustre +, Lycopus europaeus + , Lysimachia vulgaris + , Ranunculus repens + , Solanum dulcamara + , Sparganium erectum + , Typha latifolia + .

Degradált (kiszáradt), legeltetett foltjain megjelenik a lómenta (Mentha longifolia), deres szittyó (Juncus inflexus), kisvirágú füzike (Epilobium parviflorum), stb.

\section{Mocsári sásos (Caricetum acutiformis Eggler 1933)}

A vizsgált területen ritka növénytársulás. Szőnyegszerü állományokat alkot, melyekben domináns a Carex acutiformis. Termőhelyein jellemző a téli-tavaszi vízborítás, mely később visszahúzódik. Talaja azonban egész évben nedves marad. Látrányi állományfoltjai átmenetet jelentenek a magaskórós mocsárrétek (Calthion) felé. Fontosabb kísérō fajai: csermely aszat (Cirsium rivulare), sédkender (Eupatorium cannabinum), vízi peszérce (Lycopus europaeus), réti füzény (Lythrum salicaria), vízi menta (Mentha aquatica).

\section{Parti sásos (Caricetum ripariae Soó 1928)}

Feltöltödési lápokon, mélyebb fekvésű, rendszeresen elöntött területeken található, ahol jellemző a többé-kevésbé tartós vízborítás. A mocsári sásoshoz (Caricetum acutiformis) képest inkább eutróf és vízelöntéses jellegü. Szőnyegszerü állományokat alkot. A vizsgált területen ritka. A domináns parti sás (Carex riparia) fontosabb kísérő fajai: mocsári galaj (Galium palustre), vízi peszérce (Lycopus europaeus), nád (Phragmites communis), ágas békabuzogány (Sparganium erectum), ebszőlő csucsor (Solanum dulcamara), széleslevelü gyékény (Typha latifolia). 
9. Pántlikafüves (Carici gracilis-Phalaridetum / Kovács \& Máthé 1967/ Soó 1971 corr. Borhidi 1996)

Állományai azokon az időszakosan vízzel borított termőhelyeken alakulnak ki, ahol jellemző az erőteljes vízszint ingadozás. A vizsgált területen nem gyakori. Társulás felvételek (2002):

1. Phalaris arundinacea 5, Carex acutiformis 2, Calystegia sepium 1, Angelica sylvestris Caltha palustris 1, Phragmites communis 1, Stachys palustris 1, Symphythum officinale 1, Humulus lupulus +, Lysimachia vulgaris +, Lythrum salicaria +, Eupatorium cannabinum + , Rubus caesius + .

2. Phalaris arundinacea 5, Lythrum salicaria 1, Polygonum amphibium 1, Carex riparia + .

10. Szittyós láprét (Juncetum subnodulosi Koch 1926)

A vizsgált területen átszivárgásos lápokon alakultak ki állományai. Elég fajgazdag üde láprét (Caricion davallianae) jellegú társulás, amelyben a domináns nagy szittyó (Juncus subnodulosus) messziről sötétlő állománya feltünő. Mellette a csermely aszat (Cirsium rivulare) és a kétlaki macskagyökér (Valeriana dioica) fordul elö leggyakrabban. Ritkább, de jellemző a széleslevelü gyapjúsás (Eriophorum latifolium). Látránynál a mocsári nőszőfü (Epipactis palustris), fehérmájvirág (Parnassia palustris), mocsári tőzegpáfrány (Thelypteris palustris) védett fajok előfordulása jellegzetes. Elnádasodott állománya is jelentős. Társulás felvételeit az 1. táblázat tartalmazza.

11. Csátés láprét (Junco obtusiflori-Schoenetum nigricantis Allorge 1921)

Tipikus állományai domboldalban, átszivárgásos lápon alakultak ki. Érdemes megjegyezni, hogy maga a domináns, zsombékos növésü kormos csáté (Schoenus nigricans) is védett faj. Gyakoriak benne a jellemzö, üde lápréti növények, mint a barna sás (Carex hostiana), fehérmájvirág (Parnassia palustris), mocsári nöszöfü (Epipactis palustris). A Balatontól délre ugyancsak megtalálható Cladio-Schoenetumtól (Lájer 1998a) ez a társulás elsösorban abban különbözik, hogy nagyobb fajszámmal és abundanciával jelennek meg a Caricion davallianae- és a Molinietalia-jellegü fajok. Gazdagabb a mohaszint is, a vizsgált állományokban a Campylium stellatum szinte minden zsombékon megtalálható. Felvételeit a 2. táblázat tartalmazza.

12. Csetkákás keskenylevelü gyapjúsásos (Eleocharidi uniglumi-Eriophoretum angusifolii Lájer 1998)

UUde lápréti növénytársulás, amelyben domináns és nyáreleji aszpektusban feltünő a keskenylevelü gyapjúsás (Eriophorum angustifolium). Típusfelvétele a Marcal-medencében készült (részletesebben vö. Lájer 1998b). Átszivárgásos lápon, kis kiterjedésben fordul elö, a vizsgált területen fontosabb kísérő faja a mocsári zsurló (Equisetum palustre), muharsás (Carex panicea), kötő káka (Schoenoplectus tabernaemontani), csermely aszat (Cirsium rivulare), nád (Phragmites communis), az utóbbi degradáció- (eutrofizáció-)jelző.

\section{Csermely aszatos (Cirsietum rivularis Nowinski 1928)}

Állományai a völgyoldal átszivárgásos lápjai (üde láprétjei) alatt találhatóak. Termöhelyén rövid idejü vízborítás elöfordul. Talaja tartósan friss vízellátású. A Calthion-jellegü társulás fajösszetételére a Molinietalia, Caricion davallianae, Magnocaricion és Molinio-Arrhenatheretea jellegü fajok sajátos keveredése jellemző. A csermely aszat (Cirsium rivulare) május-júniusban laza felső szintet alkot. Emellett állandónak bizonyult a muharsás (Carex panicea), mocsári zsurló (Equisetum palustre), kétlaki macskagyökér (Valeriana dioica), mocsári sás (Carex acutiformis), réti boglárka (Ranunculus 
1. táblázat: Juncetum subnodulosi 1-7: Látrány. Valamennyi 10 m²$^{2}$-es mintaterületen készült 1997-ben.

\begin{tabular}{|c|c|c|c|c|c|c|c|}
\hline Faj & 1. & 2. & 3. & 4. & 5. & 6. & 7. \\
\hline \multicolumn{8}{|l|}{ Caricion davallianae } \\
\hline Carex hostiana & - & + & - & - & - & 1 & - \\
\hline Epipactis palustris & 1 & 1 & - & - & - & - & - \\
\hline Eriophorum latifolium & + & + & + & - & - & 1 & - \\
\hline Juncus subnodulosus & 4 & 4 & 3 & 3 & 3 & 4 & 5 \\
\hline Parnassia palustris & - & 1 & - & - & - & 1 & - \\
\hline Schoenus nigricans & - & - & - & - & - & + & - \\
\hline \multicolumn{8}{|l|}{ Magnocaricion } \\
\hline Carex appropinquata & - & - & + & - & - & - & - \\
\hline Carex elata & - & - & 1 & 1 & + & - & - \\
\hline \multicolumn{8}{|l|}{ Molinietalia } \\
\hline Carex panicea & + & - & 1 & - & - & + & - \\
\hline Cirsium rivulare & 1 & 1 & 2 & 2 & + & - & 1 \\
\hline Equisetum palustre & + & - & - & - & + & - & - \\
\hline Filipendula ulmaria & - & - & + & + & + & - & - \\
\hline Galium uliginosum & + & - & - & - & - & - & - \\
\hline Molinia hungarica & 1 & 2 & + & + & + & + & - \\
\hline Sanguisorba officinalis & + & + & + & + & + & 1 & - \\
\hline Selinum carvifolia & - & - & - & + & + & - & - \\
\hline Serratula tinctoria & - & + & - & - & - & 1 & - \\
\hline Succisa pratensis & - & + & - & - & - & 1 & - \\
\hline Valeriana dioica & + & 1 & + & + & - & 1 & + \\
\hline \multicolumn{8}{|l|}{ Salicion cinereae } \\
\hline Salix cinerea & + & - & - & - & - & - & - \\
\hline \multicolumn{8}{|l|}{ Alnion glutinosae } \\
\hline Thelypteris palustris & - & 2 & 4 & 3 & 4 & - & - \\
\hline \multicolumn{8}{|l|}{ Phragmitetea } \\
\hline Phragmites communis & - & 1 & - & + & + & + & + \\
\hline \multicolumn{8}{|l|}{ Molinio-Arrhenatheretea } \\
\hline Lathyrus pratensis & - & - & + & - & 1 & - & - \\
\hline Ranunculus acris & + & - & + & + & + & - & + \\
\hline \multicolumn{8}{|l|}{ Artemisietea } \\
\hline Solidago gigantea & - & - & - & 1 & 1 & - & + \\
\hline \multicolumn{8}{|l|}{ Indiff. } \\
\hline Agrostis stolonifera & - & + & - & - & - & - & - \\
\hline Angelica sylvestris & - & - & - & 1 & - & - & + \\
\hline Carex flacca & - & - & 1 & - & - & + & + \\
\hline Cirsium palustre & - & + & - & - & - & - & - \\
\hline Lotus siliquosus & - & + & - & - & - & - & - \\
\hline Lycopus europaeus & - & - & - & - & - & - & 1 \\
\hline Lysimachia vulgaris & + & + & - & - & + & - & - \\
\hline Mentha aquatica & 1 & + & - & 1 & + & + & 1 \\
\hline Poa trivialis & - & + & - & - & - & - & - \\
\hline Potentilla erecta & 1 & 1 & - & - & + & 1 & - \\
\hline Ranunculus repens & - & - & - & - & - & - & + \\
\hline \multicolumn{8}{|l|}{ Mohaszint } \\
\hline Aneura pinguis & - & 1 & - & - & - & - & - \\
\hline Bryum pallens & - & + & - & - & - & - & - \\
\hline Calliergonella cuspidata & - & 1 & 2 & 1 & 1 & - & - \\
\hline Campylium stellatum & 1 & 1 & - & 3 & 3 & 3 & 3 \\
\hline Plagiomnium elatum & - & - & 1 & - & - & - & - \\
\hline
\end{tabular}


2. táblázat: Junco obtusiflori-Schoenetum

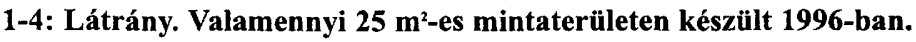

\begin{tabular}{|c|c|c|c|c|}
\hline Faj & 1. & 2. & 3. & 4. \\
\hline \multicolumn{5}{|l|}{ Caricion davallianae } \\
\hline Carex hostiana & + & 1 & 1 & 1 \\
\hline Epipactis palustris & 1 & + & + & + \\
\hline Parnassia palustris & 1 & 1 & 1 & - \\
\hline Schoenus nigricans & 3 & 5 & 4 & 4 \\
\hline \multicolumn{5}{|l|}{ Phragmition } \\
\hline Cladium mariscus & 3 & - & - & - \\
\hline \multicolumn{5}{|l|}{ Molinietalia } \\
\hline Carex panicea & + & - & - & - \\
\hline Equisetum palustre & - & - & + & - \\
\hline Galium uliginosum & + & 1 & - & - \\
\hline Molinia hungarica & 1 & - & 1 & 2 \\
\hline Orchis laxiflora ssp. palustris & - & - & - & + \\
\hline Potentilla erecta & 2 & - & 1 & 1 \\
\hline Sanguisorba officinalis & 1 & 1 & - & - \\
\hline Serratula tinctoria & + & - & 1 & + \\
\hline Succisa pratensis & + & 1 & 1 & 1 \\
\hline Valeriana dioica & + & - & 1 & 1 \\
\hline \multicolumn{5}{|l|}{ Molinio-Arrhenatheretea } \\
\hline Ranunculus acris & - & + & + & - \\
\hline \multicolumn{5}{|l|}{ Indiff. } \\
\hline Carex flacca & - & + & - & - \\
\hline Lotus siliquosus & + & + & 1 & - \\
\hline Mentha aquatica & - & 1 & - & 1 \\
\hline Phragmites communis & + & - & + & + \\
\hline \multicolumn{5}{|l|}{ Mohaszint } \\
\hline Bryum pseudotriquetrum & 1 & 1 & + & 1 \\
\hline Campylium stellatum & 1 & 1 & 1 & 1 \\
\hline Drepanocladus polycarpus & 1 & - & + & - \\
\hline
\end{tabular}

acris), vízi menta (Mentha aquatica) és mohák: Eurhynchium speciosum, Plagiomnium elatum. A társulás hasonló állományait tanulmányoztam a Dráva-völgyben (Berzence), a Marcal-medencében (Kerta és Iszkáz között), valamint a Nyírségben (Nyírábrány) is (LÁJER 1998a, 2002).

Ausztria keleti részén ez az egyik leggyakoribb Calthion-társulás (Ellmauer-Mucina, 1993).

Társulás felvételeit a 3. táblázat tartalmazza.

14. Meszes talajú kékperjés rét (Succiso-Molinietum hungaricae/Komlódi 1958/Soó 1969)

Állományai ökológiai értelemben és gyakran térben is az üde láprétek és a mocsárrétek között foglalnak helyet. Ezekben különösen nyárvégi aszpektusban domináns és fiziognómiailag meghatározó a csomós növésủ magyar kékperje (Molinia hungarica $=$ Molinia caerulea ssp. hungarica), de mellette nádképü kékperje (Molinia arundinacea) 


\section{3. táblázat: Cirsietum rivularis}

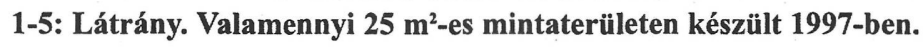

\begin{tabular}{|c|c|c|c|c|c|}
\hline Faj & 1. & 2. & 3. & 4. & 5. \\
\hline \multicolumn{6}{|l|}{ Molinietalia } \\
\hline Caltha palustris & 1 & 1 & - & - & + \\
\hline Carex panicea & 1 & + & + & + & 1 \\
\hline Cirsium rivulare & 2 & 2 & 2 & 3 & 3 \\
\hline Dactylorhiza incarnata & - & - & - & - & + \\
\hline Deschampsia caespitosa & + & + & + & + & - \\
\hline Equisetum palustre & 1 & 1 & 1 & + & 1 \\
\hline Filipendula ulmaria & + & + & + & - & - \\
\hline Galium uliginosum & - & + & - & - & - \\
\hline Lychnis flos-cuculi & - & + & - & - & - \\
\hline Sanguisorba officinalis & 1 & + & 1 & + & - \\
\hline Selinum carvifolia & 1 & 1 & 1 & + & - \\
\hline Valeriana dioica & 1 & + & 1 & + & + \\
\hline \multicolumn{6}{|l|}{ Caricion davallianae } \\
\hline Carex hostiana & + & - & - & - & - \\
\hline Juncus subnodulosus & - & 1 & 2 & 1 & 1 \\
\hline \multicolumn{6}{|l|}{ Magnocaricion } \\
\hline Carex acutiformis & 2 & 2 & + & 1 & + \\
\hline Carex elata & + & 1 & - & + & + \\
\hline Galium palustre & 1 & 1 & - & - & - \\
\hline \multicolumn{6}{|l|}{ Molinio-Arrhenatheretea } \\
\hline Cirsium canum & - & - & - & + & - \\
\hline Ranunculus acris & 1 & + & + & + & + \\
\hline \multicolumn{6}{|l|}{ Phragmitetea } \\
\hline Iris pseudacorus & + & 1 & 1 & - & - \\
\hline Phragmites communis & - & - & - & - & 1 \\
\hline \multicolumn{6}{|l|}{ Salicion cinereae } \\
\hline Salix cinerea & - & - & + & - & - \\
\hline \multicolumn{6}{|l|}{ Artemisietea } \\
\hline Solidago gigantea & - & - & + & 1 & 1 \\
\hline \multicolumn{6}{|l|}{ Indiff. } \\
\hline Angelica sylvestris & + & - & + & + & - \\
\hline Calystegia sepium & 1 & - & - & + & - \\
\hline Carex flacca & 1 & - & + & - & - \\
\hline Eleocharis palustris & - & - & - & - & + \\
\hline Galium verum & - & - & + & - & - \\
\hline Juncus articulatus & - & + & - & - & - \\
\hline Lycopus europaeus & - & + & + & + & + \\
\hline Lysimachia vulgaris & + & - & 1 & + & + \\
\hline Mentha aquatica & 1 & + & 1 & 1 & 1 \\
\hline Ranunculus repens & - & + & - & - & - \\
\hline Symphythum officinale & + & 1 & - & - & - \\
\hline \multicolumn{6}{|l|}{ Mohaszint } \\
\hline Eurhynchyum speciosum & 1 & 1 & 1 & 1 & 1 \\
\hline Plagiomnium elatum & 1 & 1 & 1 & 1 & + \\
\hline
\end{tabular}


is gyakori. Területünkön különböző degradáltsági fokú változatai találhatók. A viszonylag kevésbé zavart állományok jellegzetes kísérő faja a nyúlkömény (Selinum carvifolia), az öszi vérfü (Sanguisorba officinalis), az ördögharaptafü (Succisa pratensis), a bozontos kutyatej (Euphorbia villosa, ritka), az orvosi macskagyökér (Valeriana officinalis), a kétlaki macskagyökér (Valeriana dioica), a molyhos sás (Carex tomentosa), a deres sás (Carex flacca), a sárga borkóró (Thalictrum flavum), gyíkhagyma (Allium angulosum), lápi galaj (Galium uliginosum), tejoltó galaj (Galium verum), öszi kikerics (Colchicum autumnale), réti bolhafü (Pulicaria dysentherica, föleg a legeltetett változatban), valamint védett fajok, mint a buglyos szegfü (Dianthus superbus), a mocsári nöszöfü (Epipactis palustris) és a hússzínü ujjaskosbor (Dactylorhiza incarnata).

15. Sédbúzás mocsárrét (Agrostio-Deschampsietum caespitosae /Soó 1928/ Újvárosi 1947 Jellegzetes mocsárréti (Molinietalia) társulás, amelynek fiziognómiáját a gyepes sédbúza (Deschampsia cespitosa) csomói határozzák meg. A kísérő fajok részben közösek a kékperjés rétekkel, amelyekkel gyakran érintkeznek. Itt említhető a fehér tippan (Agrostis stolonifera), festő zsoltina (Serratula tinctoria), fekete szittyó (Juncus atratus), lápi galaj (Galium uliginosum), gyíkhagyma (Allium angulosum), vízi gamandor (Teucrium scordium), réti imola (Centaurea jacea), réti kakukkszegfü (Lychnis floscuculi), békalen (Linum catharticum), kis ezerjófü (Centaurium erythraea), érdekességként sziki cickafark (Achillea asplenifolia), továbbá a védett hússzinü ujjaskosbor (Dactylorhiza incarnata), mocsári kosbor (Orchis laxiflora ssp. palustris), stb.

A mocsárrétek jellegtelenebb (néhol kaszálórétbe átmenő), közelebbről kevéssé tanulmányozott variánsai is megtalálhatók a területen, részben a már említett nedves réti fajokkal. Megjelenik bennük a borzas füzike (Epilobium hirsutum), borzas sás (Carex hirta), fekete nadálytő (Symphythum officinale), franciaperje (Arrhenatherum elatius), közönséges galaj (Galium mollugo), közönséges szemvidító (Euphrasia stricta), lándzsás útifü (Plantago lanceolata), mezei csorbóka (Sonchus arvensis), mezei komócsin (Phleum pratense), réti here (Trifolium pratense), réti lednek (Lathyrus pratensis), réti csenkesz (Festuca pratensis), réti imola (Centaurea jacea), réti perje (Poa pratensis), szürke aszat (Cirsium canum), sárga nőszirom (Iris pseudacorus), pelyhes selyemperje (Holcus lanatus), rezgöfü (Briza media), réti boglárka (Ranunculus acris), szarvas kerep (Lotus corniculatus), árkok környékén az óriás zsurló (Equisetum telmateia) és ritkaságként az árnyéki sás (Carex umbrosa) is. Gyakran tagolják fa- és cserjesorok, illetve csoportok (Alnus glutinosa, Salix alba, Salix cinerea, Salix triandra, stb.)

\section{Homoki sztyeprét (Astragalo austriacae-Festucetum sulcatae Soó 1957)}

A vizsgált területen elterjedt zárt, rendszerint két- vagy többszintü szárazgyep-társulás, amelynek különböző degradáltsági fokú változatai alakultak ki. Viszonylag kevésbé bolygatott (csak mérsékelten legeltetett) állományaiban gyepalkotó a névadó barázdált csenkesz (Festuca rupicola $=F$. sulcata), ritkán (a természetes szukcesszióban előzetes stadiumot képviselő évelő nyílt homokpusztagyep maradványaként) a Domin homoki csenkesz (Festuca domini $=$ Festuca vaginata ssp. domini), gyakori a fenyérfü (Botriochloa ischaemum), deres tarackbúza (Agropyron intermedia), kunkorgó árvalányhaj (Stipa capillata), élesmosófü (Chrysopogon gryllus), karcsú fényperje (Koelereia cristata), helyenként a tollas szálkaperje (Brachypodium pinnatum). A meglehetösen fajgazdag társulásban az említett füfajokat részben a száraz gyepek általánosan elterjedt fajai kísérik, mint a sárga hagyma (Allium flavum), berzedt rozsnok (Bromus squarrosus), korai sás (Carex praecox), tavaszi sás (Carex caryophyllea), macskafarkú veronika (Pseudolysimachion spicatum), fogaslevelü veronika (Veronica austriaca ssp. dentata), közönséges legyezőfü (Filipendula vulgaris), közönséges napvirág (Helianthemum ovatum), pusztai kutyatej (Euphorbia seguierana), homoki pimpó (Potentilla arenaria), 


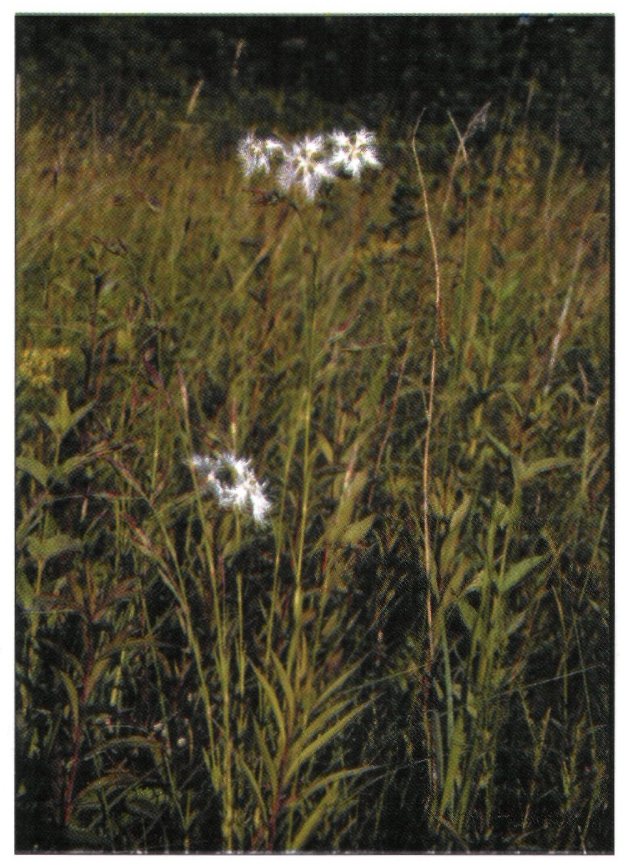

5. ábra: Buglyos szegfú (Dianthus superbus)

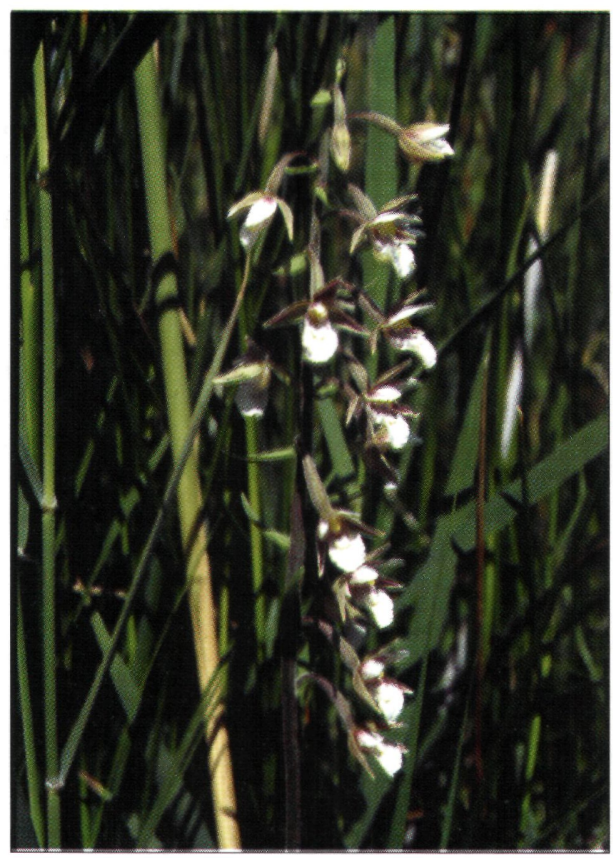

6. ábra: Mocsári nőszőfú (Epipactis palustris) 


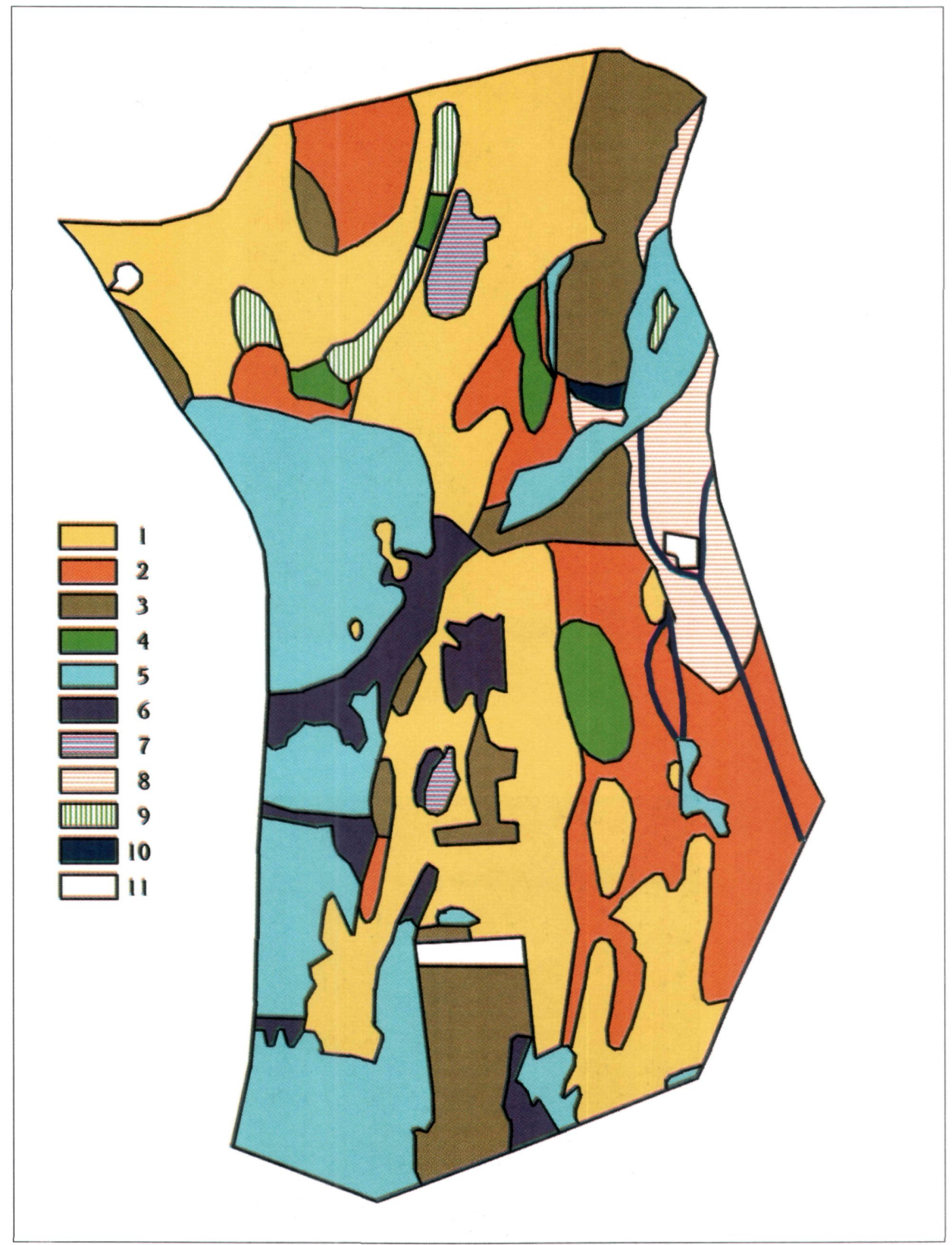

\section{7. ábra: A Látrányi Puszta Természetvédelmi Terület vegetáció térképe}

1. száraz homoki gyepek, különösen homoki sztyeprét és legeltetés miatt többé-kevésbé degradált, elgyomosodott származékai. A homokbuckák tetején a Festuce dominii nyiltabb (homokpusztarét felé közelitő) gyepje; 2. mocsárrétek (föleg kékperjés és sédbúzás rétek, csermelyaszatos, valamint legeltetés miatt elgyomosodott változataik); 3. Parlagok, gyomos területek invaziv tájidegen fajok (özöngyomok) állományaival; 4. mészkedvelő üde láprétek (Caricion davallianae); 5. haszonfa-ültetvények (a terület keleti és északi részén föként éger, a nyugati és déli részén erdei fenyő és akác, kisebb részarányban hazai lombos fafajok). Kis foltokban, fragmentálisan (délnyugaton) esetleg az eredeti keményfaligetek jellegtelenné vált maradványai; 6. spontán cserjésedő-erdősülő területek; 7. itt a cserjésedést elsősorban emberi tevékenység (ültetés) segitette elő. Nedves termőhelyeken a rekettyefüz, felhagyott anyagnyerô gödrökben a csigolyafüz, szárazabb helyeken az egybibés galagonya cserjésedése jellemző; 8. kaszálórét jellegủ és egyéb félszáraz gyepek; 9. magassásos (Zsombékos és, magassásrét), valamint nádas jellegủ társulások és legeltetés miatt elgyomosodott származékaik; 10. Fasorok, részben spontán betelepült cserjeszinttel, spontán cserjés; 11. szántóföldi kultúrák, tanyaudvarok, telephelyek. 
szürke repcsény (Erysimum diffusum), árva rozsnok (Bromus inermis), ligeti zsálya (Salvia nemorosa), mezei zsálya (Salvia pratensis), sima komócsin (Phleum phleoides), sárkerep lucerna (Medicago falcata), apró lucerna (Medicago minima), vajszínü ördögszem (Scabiosa ochroleuca), magyar kakukkfü (Thymus pannonicus), közönséges kakukkfü (Thymus odoratissimus), mezei iringó (Eryngium campestre), magyar cickafark (Achillea pannonica), mezei cickafark (Achillea collina), magyar imola (Centaurea pannonica), kőtörőszegfü (Petrorhagia saxifraga), aszúszegfü (Petrorhagia prolifera), szikár habszegfü (Silene otites), hólyagos habszegfü (Silene vulgaris), galambláb gólyaorr (Geranium columbinum), tejoltó galaj (Galium verum), borsos varjúháj (Sedum acre), Moore zsurló (Equisetum x moorei), Gyakoriak az erdőssztyepp fajok, mint a sarlós gamandor (Teucrium chamaedrys), citromkocsord (Peucedanum oreoselinum), lenlevelü zsellérke (Thesium linophyllon), sokvirágú boglárka (Ranunculus polyanthemos), osztrák ökörfarkkóró (Verbascum chaixii ssp. austriaca). Jellemzö a nyílt homokpusztagyepből viszszamaradt, Somogyból korábban ismeretlen homoki ternye (Alyssum tortuosum), továbbá a fényes sás (Carex liparicarpos), a szúrós hölgymál (Hieracium echioides), a homoki habszegfü (Silene conica), a homoki útifü (Plantago arenaria), a szürke káka (Scirpoides holoschoenus), valamint több védett faj, mint a szarvas hagyma (Allium carinatum), bunkós hagyma (Allium sphaerocephalon), szalmagyopár (Helichrysum arenarium), homoki imola (Centaurea arenaria), öszi füzértekercs (Spiranthes spiralis), fekete kökörcsin (Pulsatilla pratensis ssp. nigricans), selymes boglárka (Ranunculus illyricus) elöfordulása.

Az erősebben legeltetetett területeken zavarástürő és gyomfajok szapoprodtak el, mint az angolperje (Lolium perenne), borjúpázsit (Amthoxanthum odoratum), csillagpázsit (Cynodon dactylon), hamuka (Berteroa incana), keszegsaláta (Lactuca serriola), közönséges tarackbúza (Agropyron repens), farkas kutyatej (Euphorbia cyparissias), tövises iglice (Ononis spinosa), nyúlparéj (Chondrilla juncea), közönséges aszat (Cirsium vulgare), útszéli bogáncs (Carduus acanthoides) szamárbogáncs (Onopordum acanthium), őszi oroszlánfog (Leontodon autumnalis), keserügyökér (Picris hieracioides), kisfészkü imola (Centaurea biebersteinii), nagy bakszakáll (Tragopogon dubius), sziki kerep (Lotus glaber), tarlóhere (Trifolium arvense), szöszös bükköny (Vicia villosa ssp. pseudovillosa), szöszös ökörfarkkóró (Verbascum phlomoides), üstökös gyöngyike (Muscari comosum), ágas zsurló (Equisetum ramosissimum), mezei zsurló (Equisetum arvense).

A társulás látrányi variánsa további tanulmányozást érdemel, egyrészt mert országosan erősen veszélyeztetett és fokozott védelemre javasolt, másrészt az alföldi (ma már erősen megritkult) állományoktól bizonyos mértékig eltér (vö. FEKETE et al. 2002).

További (föként ruderális és egyéb degradált) társulások:

17. Mezei aszatos (Cirsietum lanceolati-arvensis Morariu 1943)

18. Kúpvirág-aranyvessző társulás (Rudbeckio-Solidaginetum R.Tx. \& Raabe1950 em. Soó 1961),

továbbá egyéb gyomtársulások (Apera spica-venti, Calamagrostis epigeios, Conyza canadensis, Rumex acetosa stb. állományai)

19. Keményfaliget fragmentum (közelebbröl alig besorolható), több fa- és cserjefajjal (Quercus robur, Carpinus betulus, Betula pendula, Ulmus minor, Acer campestre, Corylus avellana, Cornus sanguinea, Salix caprea, Populus alba, Ligustrum vulgare, stb.) Általánosan elterjedt lomberdei fajok (Brachypodium sylvaticum, Chaerophyllum temulum, Dryopteris filix-mas, Geranium robertianum, Geum urbanum, Hedera helix, 
Lapsana communis, Mycelis muralis, Scrophularia nodosa, Stachys sylvatica, Viola cyanea) mellett néhány viszonylag érdekesebb is található, mint az erdei csitri (Moehringia trinervia), szálkás pajzsika (Dryopteris carthusiana), szegfübogyó (Cucubalus baccifer), téli zsurló (Equisetum hyemale), varázslófü (Circaea lutetiana), stb.

20. Rozsnokos akácos (Bromo sterilis-Robinietum Pócs 1954)

és egyéb haszonfa ültetvények (égeres, erdeifenyves, korai juharos, ezüsthársas, stb.).

Felhagyott bányagödrök alján nedvességkedvelö, pionír jellegü, növényzet verődött fel, gyakori pl. az iszapsás (Carex viridula), békalen (Linum catharticum), csigolyafüz (Salix purpurea), réti füzény (Lythrum salicaria), laposszárú szittyó (Juncus compressus), gilisztaüző varádics (Tanacetum vulgare), stb.

\section{Tájidegen, invázív fajokkal (özöngyomokkal) való fertözöttség:}

A következő, ide sorolható fajok terjedése volt megfigyelhető: akác (Robinia pseudoacacia), bálványfa (Ailanthus altissima), betyárkóró (Conyza canadensis), egynyári seprence (Erigeron annuus), keresztlapu (Erechtites hieracifolia), magas aranyvesszö (Solidago gigantea), parlagfü (Ambrosia artemisiifolia), selyemkóró (Asclepias syriaca).

\section{Védett fajok:}

A vizsgált területen az alábbi védett fajok kerültek elő: agárkosbor (Orchis morio), árnyéki sás (Carex umbrosa), bugás sás (Carex paniculata), buglyos szegfü (Dianthus superbus), bunkós hagyma (Allium sphaerocephalon), fehérmájvirág (Parnassia palustris), fekete kökörcsin (Pulsatilla pratensis ssp. nigricans), homoki imola (Centaurea arenaria) homoki szalmagyopár (Helichrysum arenarium), hússzínü ujjaskosbor (Dactylorhiza incarnata), kardos madársisak (Cephalanthera longifolia), keskenylevelü gyapjúsás (Eriophorum angustifolium), kormos csáté (Schoenus nigricans), mocsári kosbor (Orchis laxiflora ssp. palustris), mocsári nőszőfü (Epipactis palustris), mocsári tőzegpáfrány (Thelypteris palustris), őszi füzértekercs (Spiranthes spiralis), rostostövü sás (Carex appropinquata), selymes boglárka (Ranunculus illyricus), szarvas hagyma (Allium carinatum), szálkás pajzsika (Dryopteris carthusiana), széleslevelü gyapjúsás (Eriophorum latifolium), téli zsurló (Equisetum hyemale), vitézkosbor (Orchis militaris). Figyelmet érdemel a Dél-Dunántúlon korábban ismeretlen mezei aggófü (Tephroseris intregrifolius)

\section{Következtetések}

Az üde láprétek növénytársulásai egész Közép-Európában visszaszorulóban vannak, ezért védelmük nemzetközi szempontból is kiemelt figyelmet érdemel. A homoki sztyeprét is országosan fokozott védelemre javasolt.

Több faj lokálisan ritka, illetve a térségben csak a vizsgált területen fordul elö: Alyssum tortuosum, Allium carinatum, Carex paniculata, Centaurea arenaria, Epipactis palustris, Eriophorum latifolium, Helichrysum arenarium, Parnassia palustris, Spiranthes spiralis, Thelypteris integrifolius, Thelypteris palustris, stb.

$\mathrm{Az}$ üde láprétek a talajvíz szintjének és minőségének változásaira igen érzékenyen reagálnak. A kiszáradás és a tápanyag bővülés egyaránt rövid idő alatt degradációjukat 
okozhatja, amelyre a vizsgált területen is bőven láthatunk példákat (elnádasodás, agreszszív tájidegen gyomok elszaporodása).

A homoki sztyepréteken a legeltetés fokozása jellegtelenné válásukat, zavarástürő és gyomfajok elszaporodását vonja maga után.

$\mathrm{Az}$ eredeti erdőtársulások már csak nagyon fragmentális, jellegtelen foltok alakjában találhatók meg. Az eredetileg feltehetően cseres-tölgyes, illetve keményfaliget jellegü termőhelyeket jelenleg legeltetés, haszonfa-termesztés és bányászat miatt nagyrészt másodlagos növényzet borítja.

\section{Köszönetnyilvánítás}

Jelen munkához értékes kiegészítő adatokkal járult hozzá Dr. Ábrahám Levente és Rozner György. Segítségüket ezúton is köszönöm.

\section{Irodalom}

BORHIDI A. 1995: Social behaviour types, their naturalness and relative ecological indicator values of the higher plants of the Hungarian Flora. Acta Bot. Hung. 39: 97-182.

BoRHIDI A.-SÁNTA A. (eds.) 1999: Vörös könyv Magyarország növénytársulásairól I-Il. - Természetbúvár Alapitvány Kiadó, Budapest. pp.1-362, 1-404.

DiersChKe, H. 1994: Pflanzensoziologie. Grundlagen und Methoden. Eugen Ulmer, Stuttgart. pp. 1.678

Ellmauer T. \& Mucina L. 1993: Molinio-Arrhenatheretea. In Mucina, L., Grabherr, G. \& Ellmauer, T.: Pflanzengesellschaften Österreichs. Teil I. Anthropogene Vegetation. New York. pp. 1-578.

FEKETE G.-MolnÁR Zs.-Kun A.-VIRÁGH K.-BotTA-DUKÁt Z. 2002: Záródó homokpusztagyep a Duna-Tisza közén: a Festuca wagneri gyepjei. P. 381-414 in "Magyar botanikai kutatások az ezredfordulón. Tanulmányok Borhidi Attila 70. születésnapja tiszteletére", szerk. Salamon-Albert É., PTE Növénytan Tanszék, Pécs pp. 1-710.

KovÁcs M. 1955: Dic zönologischen und ökologischen Verhältnisse vom Cladietum marisci in der Gegend des Balaton Secs. - Acta Bot. Hung. 2: 133-146.

LÁJER K. 1997: A Marcal-medence déli részének lápi és lápréti növénytársulásai. - Kitaibelia 2(2): 281-289.

LÁJER K. 1998a: Újabb adatok Belső-Somogy flórájának és vegetációjának ismeretéhez. - Somogyi Múzeumok Közleményei 13: 217-239.

LÁJER K. 1998b: Bevezetés a magyarországi lápok vegetáció-ökológiájába. - Tilia 6:84-238.

LÁJER K. 1998c: Az Aldrovanda vesiculosa L. újabb előfordulása és egyéb adatok Magyarország flórájának ismeretéhez. - Kitaibelia 3(2): 263-274.

LÁJER K. 2002: Florisztikai és cönológiai vizsgálatok a somogyi Dráva-völgy rétjein. - Kitaibelia 7(2): 187-205.

SIMON T.2000: A magyarországi edényes flóra határozója. Nemzeti Tankönyvkiadó, Budapest. pp. 1-846. 


\section{On the vegetation of the Látrányi Puszta Nature Conservation Area}

\section{LÁJER KONRÁD}

"Látrányi Puszta" is a protected area in Somogy county, Hungary. The plant communities of this area were investigated by the methods of classical phytosociology: Phragmitetum communis, Typhetum angustifoliae, Typhetum latifoliae, Cladietum marisci, Bolboschoenetum maritimi, Caricetum elatae. Caricetum acutiformis, Caricetum ripariae, Carici gracilis-Phalaridetum, Juncetum subnodulosi, Junco obtusiflori-Schoenetum, Eleocharidi uniglumi-Eriophoretum angusifolii, Cirsietum rivularis, Succiso-Molinietum hungaricae, Agrostio-Deschampsietum caespitosae, AstragaloFestucetum rupicolae, Cirsietum lanceolati-arvensis, Rudbeckio-Solidaginetum, Bromo sterilis-Robinietum and some others (Alnion fraction, not specified ruderal communities, wood plantations).

The occurrence of diagnostic, typical, protected, invasive or other remarkable species are detailed. The occurrence of the following protected species was established: Allium carinatum, Allium sphaerocephalon, Carex appropinquata, Carex paniculata, Carex umbrosa, Centaurea arenaria, Cephalanthera longifolia, Dactylorhiza incarnata, Dryopteris carthusiana, Dianthus superbus, Epipactis palustris, Equisetum hyemale, Eriophorum angustifolium, Eriophorum latifolium, Helichrysum arenarium, Orchis laxiflora ssp. palustris, Orchis militaris, Orchis morio, Parnassia palustris, Pulsatilla pratensis ssp. nigricans, Ranunculus illyricus, Schoenus nigricans, Spiranthes spiralis, Thelypteris palustris. Further remarkable species previously not found in the region are Alyssum tortuosum and Tephroseris integrifolius. 